\title{
Land Cover Change Impact on Coastal Tourism Development near Pacitan Southern Ringroad
}

\author{
${ }^{1}$ RISWANDHA RISANG AJI, ${ }^{2}$ VISILYA FANIZA

\begin{abstract}
${ }^{1}$ Urban and Regional Planning, Bandung Islamic University, Jl. Tamansari 24 Bandung, ${ }^{2}$ Urban and Regional Planning, Diponegoro University, Jl. Prof. Sudarto Tembalang Semarang. email: ${ }^{1}$ riswandha@unisba.ac.id; ${ }^{2}$ visilya.faniza19@pwk.undip.ac.id
\end{abstract}

\begin{abstract}
Tourism is one of the economic sectors that can make a difference to the regional economy. Pacitan Regency is one of the regions which has tourism sector as its income. Pacitan regency also has Southern Ringroad that opens access to some coastal areas. Coastal areas have some tourism potentials, especially beach tourism. The aim of this research is to describe land cover change and its impacts on three beaches as coastal tourism areas due to the development of the southern ringroad. This research uses descriptive analysis to describe land cover change using remote sensing analysis and social-economic development in the coastal tourism area. Satellite images from Landsat 7 are analyzed to describe the land cover change. The result of this research shows that there is the land cover change which leads to social and economic development. Social development in the area is concluded not vulnerable and economic development is improved.
\end{abstract}

Keywords: land cover change, remote sensing analysis, tourism development

\section{Introduction}

Remote sensing depicted certain objects on the surface of the earth complete with the shape and location of the objects. Remote sensing digital images were recorded by the system through sensors mounted on satellites, which was obtained through the reflections record process, emittance, or backscatter electromagnetic waves by using optical-electronic sensors. Currently, there are various of satellite imagery available, such as Landsat, SPOT, ALOS, IKONOS, Quickbird, Google Earth, SAS Planet, etc. (Danoedoro, 2012).

Landsat (Land satellite) was one of the public satellite imagery providers to analyze remote sensing researches and easy to obtain. The Landsat series has been started since 1972 and has been improved ever since. In 1999, Landsat-7 was launched with multi-spectral sensors (Landsat-7 ETM+) and contained eight bands (Danoedoro, 2012). The Landsat-7 ETM+ satellite images of the world are available free on the USGS
Earth Explorer with various time records.

The implementation of Landsat-7 ETM+ data analysis in this research is intended to show the land covers conversion and its impact on rural tourism development due to the construction of the Southern Ringroad. The construction of the Southern Ringroad itself began in 2008, completed and inaugurated in 2013. From 2008 until recently, the land cover changes still occurred in the surrounding area.

The satellite imagery is used to depict the conversion of land cover from 2008 to 2020 at Southern Ringroad in Pacitan Regency. It is used to obtain information about the land cover conversion due to the physical development in the surrounding rural tourism area. However, physical development must be planned carefully to keep its environment sustainable (Sangchumnong, 2018). Tourism is one of the highest contributors toward Pacitan Regency's GDP (Aji, 2020). Tourism contributes to region's GDP through transportation, accommodation, information,

Received: September 05, 2020, Revision: March 30, 2021, Accepted: June 08, 2021

Print ISSN: 0215-8175; Online ISSN: 2303-2499. DOI: https://doi.org/10.29313/mimbar.v37i1.6620

Accredited Sinta 2 based on the decree No.10/E/KPT/2019 until 2024. Indexed by DOAJ, Sinta, Garuda, Crossreff, Dimensions 
company, health, and education sectors (Aji, Pramono and Rahmi, 2018).

Infrastructure development could influence the value of tourism in an area. While in its development, tourism also attracts the physical development which could then change the social and economic order of the people who live around it. However, in order to maintain the tourism sustainability, whether its environment or its social aspects, the physical ability must be developed by green economy (Pan et al., 2018). In this research, the construction of the Southern Ringroad was the starting point for the development of tourism in the surrounding area (Fig 1.)

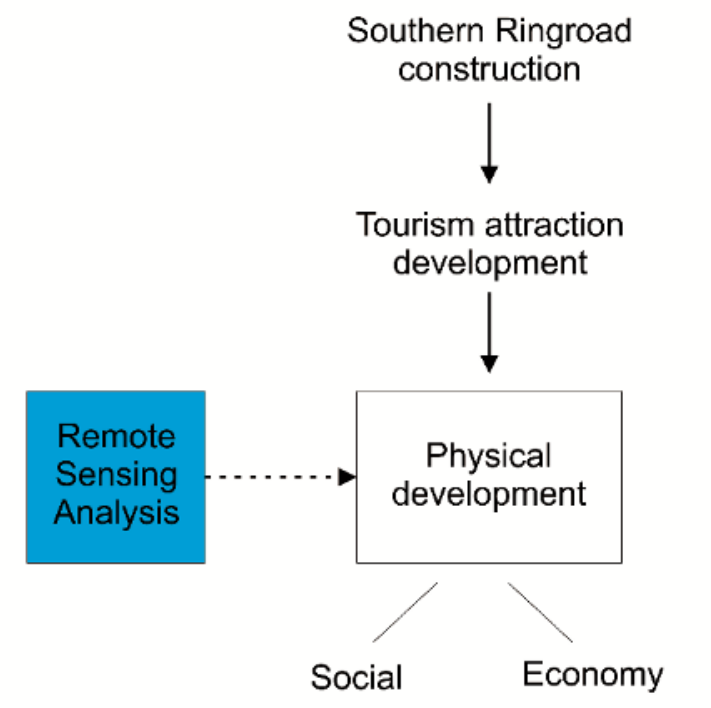

Figure 1. Research framework. Remote sensing analysis is used to depict physical development which ignited by tourism attraction development. The physical development then initiates social development and economy development in surrounding communities which lead to rural development in that area.

Tourism is one of the developed sectors which can increase the local economy in certain places that have tourism potentials (Hsu, 2019). Pacitan Regency has abundant modern coastal tourism areas that are professionally managed as well as locally managed ones. Most of the tourism managements in Pacitan Regency utilized local resources as the value chains from benefiting resources for sustainable tourism (Sanches-Pereira et al., 2017).

The case study of this research is located in the rural area near the Southern Ringroad in Pacitan Regency. The Southern Ringroad was inaugurated on August 22nd,
2013. The construction of the Southern Ringroad opened the accessibility of certain rural area, namely Sidomulyo village, Hadiwarno village, and Pager Kidul village (Fig. 2). Sidomulyo and Hadiwarno village are located in Ngadirojo district, while Pager Kidul village is located in Sudimoro district. The Southern Ringroad made those three villages more accessible from Pacitan city centre because the Southern Ringroad cut the terrains that obstruct the access to those areas. All of those three villages had coastal tourism potentials. Sidomulyo village has Soge beach, Hadiwarno village has Taman beach, and Pager Kidul village has Kunir beach. Whilst those villages rural area ha opened, it also makes the tourism potentials in each village more accessible. Therefore, tourism-based development in these areas is growing.

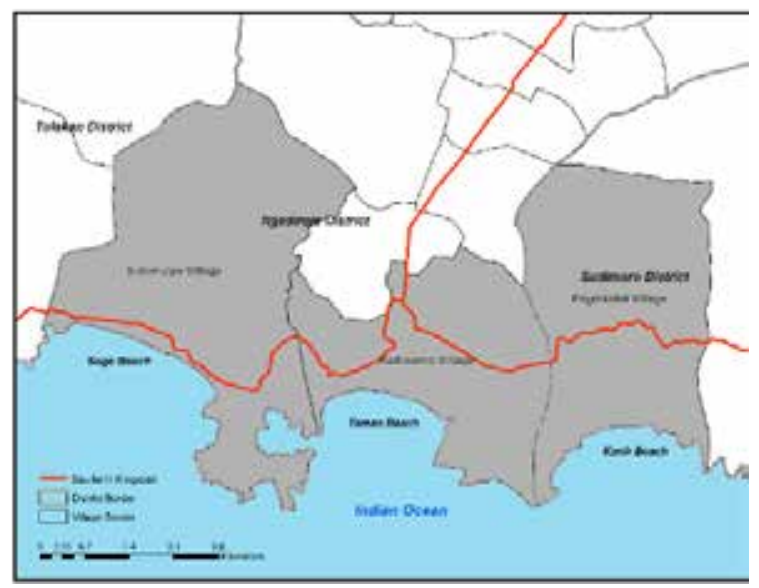

Figure 2. Administrative Map of the Research Area. Research locations are in Sidomulyo village, Hadiwarno village, and Pager Kidul village. Sidomulyo and Hadiwarno village are located in Ngadirojo district, while Pager Kidul village is located in Sudimoro district. Sidomulyo village has Soge beach. Hadiwarno village has Taman beach. Pager Kidul village has Kunir beach.

All of the tourism potentials in those villages were based on natural resources. Soge Beach was known as a tourism destination based on natural resources consisting of beaches and pine forests as a deterrent for abrasion. Taman beach was another tourism destination based on natural resources consisting of turtle natural habitat and white sand beach. Kunir beach was a tourism spot based on natural resources consisting of white sand beach and it had shipwreck as a tourism attraction. Naturebased tourism needed special handling in developing it (Mandić, 2019). Due to the development of those three beaches, 
the surrounding rural area which was still in the administrative area of Sidomulyo, Hadiwarno, and Pager Kidul village was also developing. Ideal development could be reached by balancing economic, social, and environmental development (Aquino, Lück and Schänzel, 2018). Rural development could be reached by economic tourism which opened in that area. Local community's economy was improved by its tourism destination (Liu and Wu, 2019).

Related to the tourism component, such as attractions, amenities, and accessibility (Manrai, Lascu and Manrai, 2019), the Southern Ringroad helped Soge, Taman, and Kunir in their developments. Those attractions were potential for regional tourism and had been opened since the Southern Ringroad was made. Soge, Taman, and Kunir tourism attractions are located right on the south side of the road. Therefore, it was necessary to protect Soge, Taman and Kunir tourism attractions based in the natural system. On the coast of Soge, there was also a pine forest that serves as a barrier to abrasion. Also, there was a river that flows towards the coast of Soge which was also used as a tourist attraction. Taman beach also had a whitesand coastline as natural resources. Taman beach had other attractions such as turtle natural habitat, 500 meters flying fox, and swimming pool. Meanwhile, Kunir beach has a white-sand coastline as its main attraction. The opening of this attraction resulted in the development of the surrounding area in the form of rural development (Manrai, Manrai and Friedeborn, 2018).

The Southern Ringroad construction was not only developing these beaches attractions, but also the amenities. The variety of amenities available at Soge, Taman, and Kunir such as food stall, souvenirs shop, toilets, and praying room are growing every year. The development of these coastal areas caused an increase in the number of amenities from those on the south side of the Southern Ringroad to spread to the north side of the Southern Ringroad. Tourism amenities influenced rural development through amenity developments in these beaches coastal area. The communities could build amenities to support tourism activities on these beaches (Margaryan and Fredman, 2017). However, tourism development must consider the environment sustainability by not developing out of the region carrying capacity (Nitivattananon and Srinonil, 2019).
The Southern Ringroad itself was the main access to these beaches. Even all these beaches had not been opened as a tourism destination before the Southern Ringroad was inaugurated. The existence of the road as a transportation infrastructure could have an impact on accessibility to tourism destinations. The existence of the Southern Ringroad also brought rural development to these beaches tourism area by bringing access to its location from Pacitan city centre. Infrastructure could help tourism destinations to grow and develop faster (Jin et al., 2020).

The development of the tourism component will certainly be changed along with the physical changes in the tourism area. These physical changes were the main issues in this case study. Physical change in land cover was seen through satellite imagery to find out how the conversion had taken place in Sidomulyo, Hadiwarno, and Pager Kidul village since these beaches started to open until recently in 2020. Physical changes will certainly went side by side with social and economic developments in the Soge, Taman, and Kunir beaches tourism area which could lead to the increase in social vulnerability (Faniza and Pradoto, 2019). Social vulnerability could be assessed by social and economic variables. Social assessment variable in this research was population density, while economic assessment variable is community income.

Social development in the tourism area was certainly inseparable from the development of tourism itself. Social development in the community around the location of tourism was a multiplier effect of the development of tourism in the form of changes in people's livelihoods towards tourism livelihoods (Su, Wall and Wang, 2019).

The economic development of the surrounding community could be seen from the development of regional income in the research location. Tourism would have an impact on the sectors that form it. Economic development may increase livelihood in tourism area (Lasso and Dahles, 2018).

\section{Research Methodology}

This research took place in Sidomulyo, Hadiwarno, and Pager Kidul Village, where the focus was on the tourism spots of the beaches in these villages (Soge, Taman, and 
Kunir Beach). Sidomulyo and Hadiwarno Village are located in Ngadirojo District, while Pager Kidul Village is located in Sudimoro District. This research used remote sensing and the descriptive analysis method.

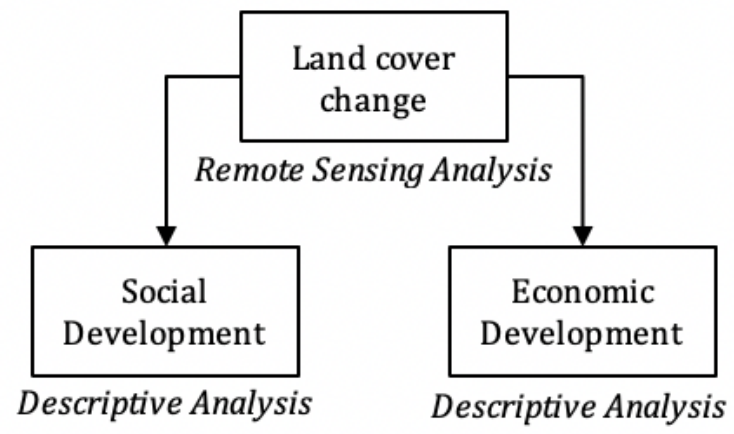

Figure 3. Analysis Framework

The development of rural areas depends on the accessibility of the areas. Based on the basic analysis, Soge and Taman beach are located close to the Southern Ringroad. Meanwhile, Kunir beach is located at least $1.5 \mathrm{~km}$ away from the Southern Ringroad.

The primary data for this research was obtained from USGS Earth Explorer, which are the satellite imageries of Landsat 7 ETM+. This research used the combination of band 5 (red), band 4 (green), and band 3 (blue) which produced the output of vegetation and water display. In this combination, another colour was also visible that indicates the non-vegetative and non-water land cover so that it could be concluded that this land cover was built-up area.

The satellite image analysis was the comparison of the land cover between 2008 and 2020 (current condition) to analyze the impact of the Southern Ringroad development. The satellite imagery of 2008 showed the land use when Southern Ringroad construction was started, while the imagery of 2020 showed the most recent land use. The changes in land use were considered as the impact of increasing tourism development in the study area. The increasing development and tourism also meant changes in the economic and social of the community in the area. The remote sensing analysis framework for this research could be seen in the following figure.

This research also used the supporting data from the Development Planning Agency (Badan Perencanaan Pembangunan Daerah/ BAPPEDA) Pacitan Regency. The data used were the road network and administrative

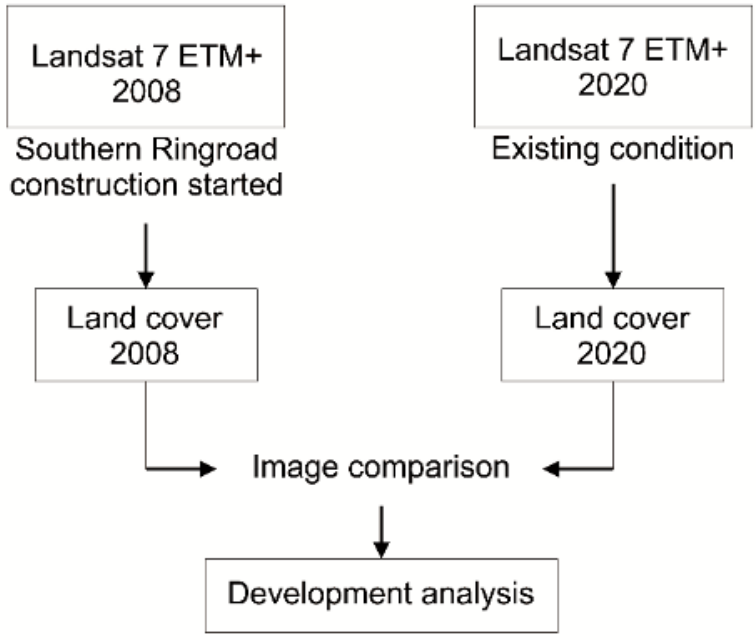

Figure 4. Remote Sensing Analysis Framework

boundaries shapefile. These data supported the visual information of the road network and the limit of the study area.

The result of the remote sensing analysis was the land cover changes since the construction of the Southern Ringroad until the most recent time. Descriptive analysis was used to describe the physical change in research location. To justify the land cover analysis, the detail information about development types was figured by the Google Maps Satellite Imagery. Descriptive analysis was also used to describe social and economic development in the research location.

Social assessment was analyzed by scoring method by using Likert scale. The score of population density was based on population density per kilometre. The denser the area, the more vulnerable the area was. Population density was measured by the following formulation:

Table 1

Population Density Scoring

\begin{tabular}{ccc}
\hline No & Density $\left(\right.$ Population $\left./ \mathrm{km}^{2}\right)$ & Score \\
\hline 1 & $<500$ & 5 \\
2 & $500-1249$ & 4 \\
3 & $1250-2499$ & 3 \\
4 & $2500-3000$ & 2 \\
5 & $>3000$ & 1 \\
\hline
\end{tabular}

Source: Faniza and Pradoto, 2019 


\section{Result and Discussion}

\section{Land Cover Analysis}

The remote sensing result showed that there are several changes in land cover nearby the Southern Ringroad in the study area. These changes were mostly located near the beaches and the northern part of the Ringroad towards settlement and business along the Southern Ringroad. The details about the land covers in 2008 and 2020 could be seen in the following figures.

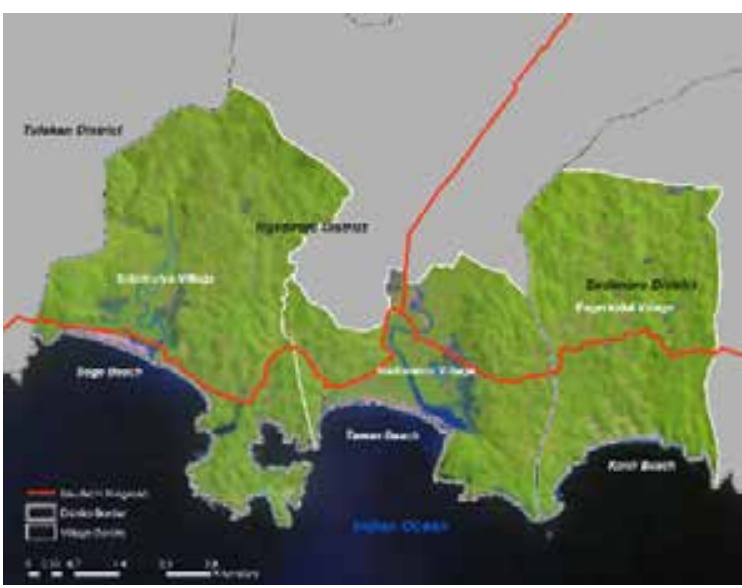

Figure 5. Land cover of Sidomulyo, Hadiwarno, and Pager Kidul village in 2008

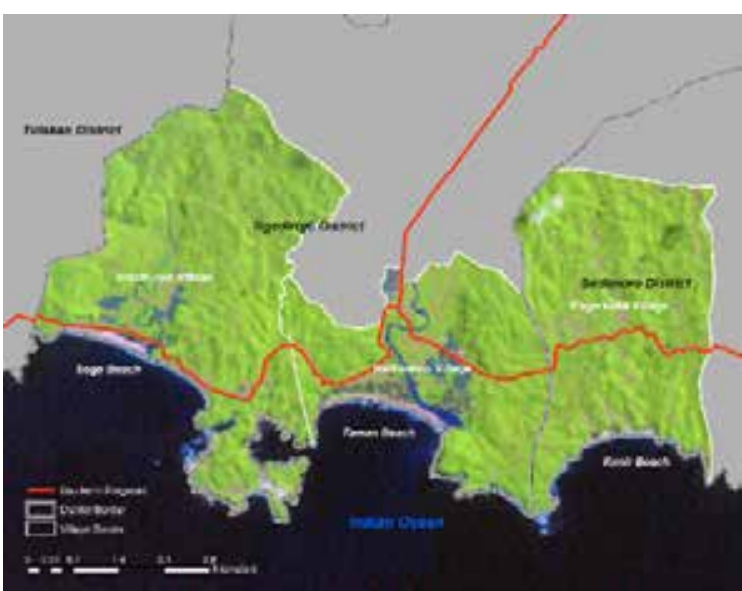

Figure 6. Land cover of Sidomulyo, Hadiwarno, and Pager Kidul village in 2020

In Sidomulyo village, the development happened in the northern part where most settlements were located. The settlements have been built since 2008 and kept expanding along with the population growth. Local communities utilized the tourism for their livelihood as the sustainability aspects (Su, Wall and Wang, 2019). The satellite imagery of Google Maps in 2020 showed that the development along the Southern Ringroad was toward the business to support the tourism activities in Soge beach (Fig. 6).

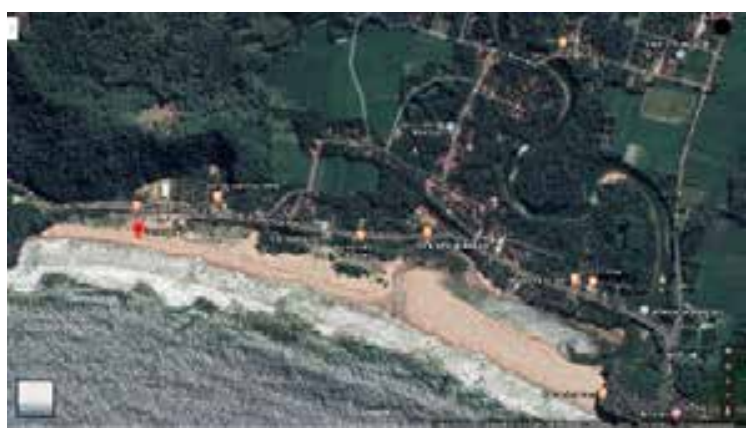

Figure 7. Google Maps Satellite Imagery of Soge Beach in 2020

Taman beach in Hadiwarno village had its tourism attraction, which was the turtle sanctuary. Similar to Soge beach, Taman beach also developed towards the tourism industry near the Southern Ringroad. Based on the comparison of the land cover in 2008 and 2020, this area was the most developing than the other two tourism spots. From the satellite imagery of Google Maps in 2020, it could be seen that the built-up area was mostly in the southern part of the road (Fig.7). The accessibility to this tourism spot also well provided, thus it helped the development of the social and economic sector in the nearby area. Local community developed the tourism site side by side with their sustainable development concept by maintaining tourism site's environment (Lee and Jan, 2019).

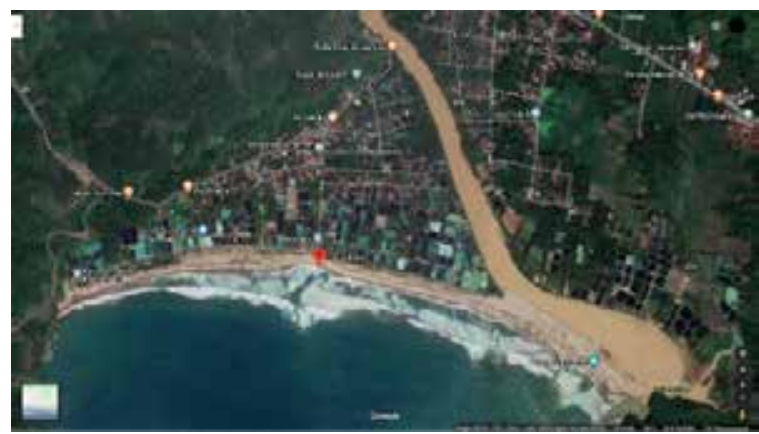

Figure 8. Google Maps Satellite Imagery of Taman Beach in 2020

Meanwhile, in Kunir beach of Pager Kidul village, tourism development was less than two other beaches. The distance of the main Southern Ringroad to the beach location is estimated $1.5 \mathrm{~km}$ where the land covers in between was mostly vegetation. However, the development of the settlements was kept growing near the Southern Ringroad (Fig.8). 


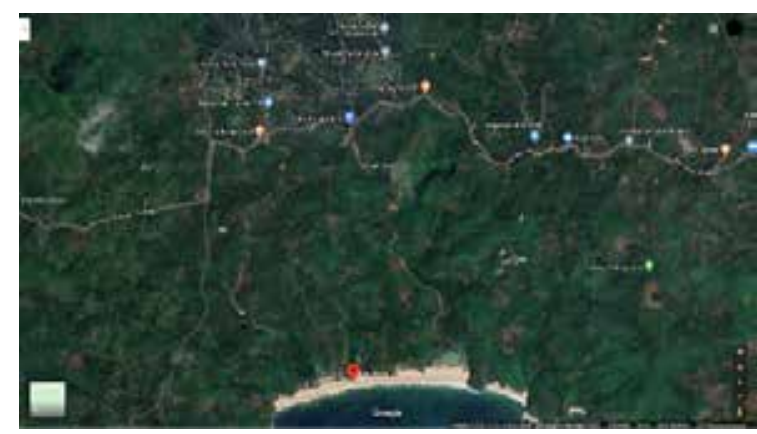

Figure 9. Google Maps Satellite Imagery of Kunir Beach in 2020

\section{Social Development}

The livelihoods of the people of Sidomulyo, Hadiwarno, and Pager Kidul village varied with the majority of the population being farmers. As a rural community, this is certainly a common thing. Sidomulyo, Hadiwarno, and Pager Kidul village were dominated by agricultural land. Community activities and original environment could be developed as tourism activities (Haryani and Huda, 2018). These lands had potential social advantage of agricultural tourism. Government support was needed and it was an essential element to develop an agricultural tourism besides professional planner and businesses (Fitriana, 2017). Cooperation between stakeholders could raise the economic level of the area (Ahmad and Thahir, 2017). Unfortunately, the government was not giving any support to develop any agricultural tourism.

The development of Soge, Taman, and Kunir beach had caused people who were farmers to have side jobs in tourism sector. Before these beaches opened as one of the tourism destinations in Pacitan Regency, the majority of residents who worked in the agricultural sector had only one main income from agricultural products. But after the Soge, Taman, and Kunir beach opened as a tourism destination, the residents of Sidomulyo, Hadiwarno, and Pager Kidul village had additional income from the tourism sector such as selling things/foods in the tourism area, becoming a tour guide, and working in the tourism administration sector.

Social development occurred in Sidomulyo and Hadiwarno was the community had an alternate occupation in the tourism sector such as becoming amenities workers, working in tourism management, and as administrator. While in Pager Kidul, there was less change in community livelihood.
Most dominant management influence was the variation of tourism activities (Wijayanti et al., 2018). Agricultural tourism could be one of the alternative additionals to the variation of tourism activities in Sidomulyo, Hadiwarno, and Pager Kidul.

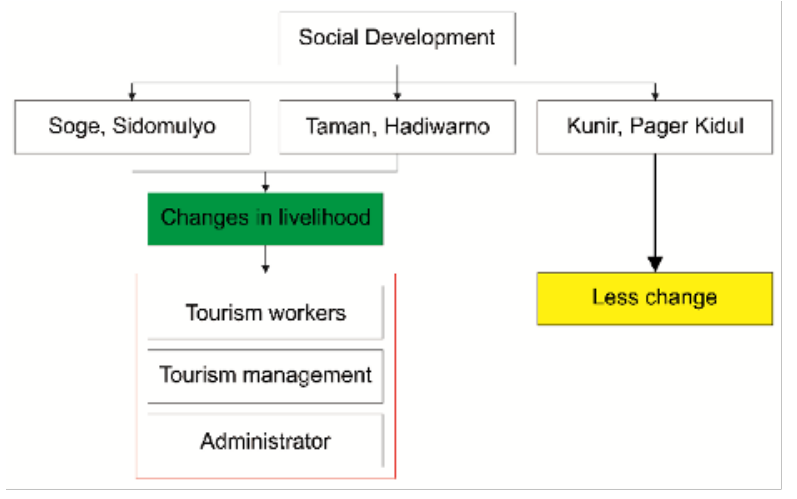

Figure 10. Social Development in Community. Changes in livelihood are depicted in Soge and Taman. New jobs in the tourism sectors such as tourism worker, tourism management, and administrator make a social development in the rural area.

Social assessment variable for social vulnerability shows Sidomulyo and Pager Kidul got the score of 5 , while Hadiwarno got the score of 4 from the scale 1-5, where 1 is the most vulnerable and 5 is the most resilient. This means that social development in Soge, Taman, and Kunir beaches is not on a vulnerable state.

Table 2

Population Density Score

\begin{tabular}{ccccc}
\hline Village & Population & Area & Density & Score \\
\hline $\begin{array}{c}\text { Sido- } \\
\text { mulyo }\end{array}$ & 4675 & 16,43 & 285 & 5 \\
$\begin{array}{c}\text { Hadi- } \\
\text { warno }\end{array}$ & 3898 & 7,73 & 504 & 4 \\
$\begin{array}{c}\text { Pager } \\
\text { Kidul }\end{array}$ & 3249 & 10,54 & 308 & 5 \\
\hline
\end{tabular}

Source: Researchers, 2020

\section{Economic Development}

Economic activity in the village of Sidomulyo, Hadiwarno, and Pager Kidul had grown since Soge, Taman, and Kunir beaches opened as a tourism destination. Economic activities include selling things in the tourism area as an amenity for tourist needs. Economic activities developed from previously only buying and selling in the market before the Soge, Taman, and Kunir beaches opened for tourism destination to 
economic activities related to tourism in Soge, Taman, and Kunir beaches tourism area.

Economic development in Sidomulyo and Hadiwarno occurred through additional work of becoming amenities worker and tourism administrator at the tourism sector that provides income for the residents. While in Pager Kidul there was no change of community livelihood. The involvement of local community in tourism development could affect the economic impact of tourism on the local community (Wildan, Sukardi and Syuaib, 2016). Economic empowerment was needed to develop tourism business for the local community (Muslim, 2016). Sidomulyo, Hadiwarno, and Pager Kidul needed to develop community empowerment to increase economic level of the area.

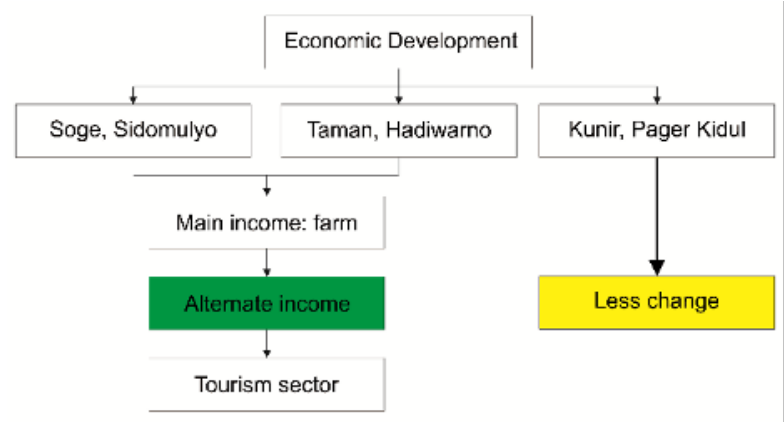

Figure 11. Economic Development in the Community. Communities in Soge and Taman get alternate income from tourism sector jobs while their main income is still intact. This leads to economic development in that rural area.

\section{Conclusions}

The result of satellite imageries analysis shows that Soge beach and Taman beach were well developed because they had decent accessibility and supported by the Southern Ringroad which increased the attractiveness of Soge beach and Taman beach. The accessibility to Soge beach and Taman beach had resulted in socioeconomic developments in the surrounding community. Meanwhile, Kunir Beach was not well developed due to its low accessibility. Kunir Beach is too far from the Southern Ringroad so that it lacked tourism appeal. This also caused the socio-economic development of the surrounding community was not too good. The process to develop rural areas that have tourism potential could be done by developing potential tourism attractions that the region had by providing decent accessibility so that it could develop the socio-economic of the surrounding communities.

Based on the results of the analysis, there were physical changes in the coastal area along the Southern Ringroad. The land cover changes were considered as the result of the tourism development along the Pacitan Regency Southern Ringroad. Social developments that occurred in Sidomulyo, Hadiwarno, and Pager Kidul village changed the livelihoods of the communities from agricultural to the tourism sector or having additional income from the tourism sector. The economic development that occurred in Sidomulyo, Hadiwarno, and Pager Kidul village was related to the increase in community income through economic activities carried out in the Soge, Taman, and Kunir beach tourism areas.

The development of rural tourism area should consider more on the sustainability of the physical, social, and economic aspects. Local government should develop the tourism with green economy and green infrastructure concept to sustain the environment. The balance of these three aspects is expected to give better livelihood especially to the community living in the surrounding area. Therefore, stakeholders should consider the needs of rural tourism area to achieve integrated sustainable development.

\section{References}

Ahmad, B. and Thahir, F. S. P. R. (2017) 'The Partnership of Maritime Tourism Management in Kapoposang Island Pangkajene Regency', MIMBAR, 33(1), pp. 182-190.

Aji, R. R. (2020) 'Komponen Pariwisata Pantai dalam Ekonomi Wilayah Kabupaten Gunungkidul', ETHOS (Jurnal Penelitian dan Pengabdian), 8(1), pp. 9-15. doi: 10.29313/ethos.v8i1.4929.

Aji, R. R., Pramono, R. W. D. and Rahmi, D. H. (2018) 'Kontribusi Sektor Pariwisata Terhadap Ekonomi Wilayah Di Provinsi Jawa Timur', Jurnal Planoearth, 3(2), pp. 57-62. doi: 10.31764/jpe.v3i2.600.

Aquino, R. S., Lück, M. and Schänzel, H. A. (2018) 'A conceptual framework of tourism social entrepreneurship for sustainable community development', Journal of Hospitality and Tourism Management. Elsevier Ltd, 37(March), pp. 23-32. doi: 10.1016/j.jhtm.2018.09.001.

Danoedoro, P. (2012) Pengantar 
Penginderaan Jauh Digital. Yogyakarta: ANDI Publisher.

Faniza, V. and Pradoto, W. (2019) 'SocioEcological Vulnerability Assessment and the Resulting in Spatial Pattern: A Case Study of Semarang City', BHUMI: Jurnal Agraria dan Pertanahan, 5(3 (special Edition)), pp. 93-100. doi: 10.31292/ jb.v5i3.3.

Fitriana, W. (2017) 'The Role of Triple Helix Actors for Agro Tourism Development in West Sumatera', MIMBAR, 33(2), pp. 219-227. doi: dx.doi.org/10.29313/ mimbar.v33i2.2098.219-227.

Haryani and Huda, N. (2018) 'Developing Fishing Tourism Destination Based on "Anak Nagari" Concept in Padang City', MIMBAR, 34(1), pp. 51-60. doi: dx.doi. org/10.29313/mimbar.v34i1.2990.5160.

Hsu, P. H. (2019) 'Economic impact of wetland ecotourism: An empirical study of Taiwan's Cigu Lagoon area', Tourism Management Perspectives. Elsevier, 29(April 2018), pp. 31-40. doi: 10.1016/j.tmp.2018.10.003.

Jin, S.etal. (2020)'Theinfluence of high-speed rail on ice-snow tourism in northeastern China', Tourism Management. Elsevier Ltd, 78(May 2019), p. 104070. doi: 10.1016/j.tourman.2019.104070.

Lasso, A. and Dahles, H. (2018) 'Are tourism livelihoods sustainable? Tourism developmentandeconomictransformation on Komodo Island, Indonesia', Asia Pacific Journal of Tourism Research. Taylor \& Francis, 23(5), pp. 473-485. doi: 10.1080/10941665.2018.1467939.

Lee, T. H. and Jan, F. (2019) 'Can communitybased tourism contribute to sustainable development ? Evidence from residents ' perceptions of the sustainability', Tourism Management. Elsevier, 70(September 2017), pp. 368-380. doi: $10.1016 / j$. tourman.2018.09.003.

Liu, A. and Wu, D. C. (2019) 'Tourism productivity and economic growth', Annals of Tourism Research. Elsevier, 76(November 2018), pp. 253-265. doi: 10.1016/j.annals.2019.04.005.

Mandić, A. (2019) 'Nature-based solutions for sustainable tourism development in protected natural areas: a review', Environment Systems and Decisions. Springer US. doi: 10.1007/s10669-01909718-2.

Manrai, L. A., Lascu, D. and Manrai, A. K. (2019) 'A study of safari tourism in sub-Saharan Africa: An empirical test of Tourism A-B-C ( T-ABC ) model', Journal of Business Research. Elsevier, (August 2018), pp. 0-1. doi: 10.1016/j. jbusres.2019.02.066.

Manrai, L. A., Manrai, A. K. and Friedeborn, S. (2018) 'Environmental determinants of destination competitiveness and its Tourism Attractions-Basics-Context, A-B-C, indicators', Journal of Economics, Finance and Administrative Science. doi: 10.1108/jefas-01-2018-0010.

Margaryan, L. and Fredman, P. (2017) 'Natural amenities and the regional distribution of nature-based tourism supply in Sweden', Scandinavian Journal of Hospitality and Tourism, 17(2), pp. 145-159. doi: 10.1080/15022250.2016.1153430.

Muslim, A. (2016) 'Economic Community Empowerment Through Tourist Village Development', MIMBAR, 32(2), pp. 343352.

Nitivattananon, V. and Srinonil, S. (2019) 'Enhancing coastal areas governance for sustainable tourism in the context of urbanization and climate change in eastern Thailand', Advances in Climate Change Research. Elsevier Ltd, 10(1), pp. 47-58. doi: 10.1016/j. accre.2019.03.003.

Pan, S. Y. et al. (2018) 'Advances and challenges in sustainable tourism toward a green economy', Science of the Total Environment. Elsevier B.V., 635, pp. 452-469. doi: 10.1016/j. scitotenv.2018.04.134.

Sanches-Pereira, A. et al. (2017) 'Fostering local sustainable development in Tanzania by enhancing linkages between tourism and small-scale agriculture', Journal of Cleaner Production, 162, pp. 1567-1581. doi: $10.1016 / j$.jclepro.2017.06.164.

Sangchumnong, A. (2018) 'Development of a sustainable tourist destination based on the creative economy : A case study of Klong Kone Mangrove', Kasetsart Journal of Social Sciences. Elsevier Ltd, pp. 1-8. doi: 10.1016/j.kjss.2018.02.002.

Su, M. M., Wall, G. and Wang, Y. (2019) 'Integrating tea and tourism: a sustainable livelihoods approach', Journal of Sustainable Tourism. Routledge, 27(10), pp. 1591-1608. doi: 10.1080/09669582.2019.1648482.

Wijayanti, A. et al. (2018) 'Analysis of Educational Tourism Management at Smart Park, Yogyakarta, Indonesia', MIMBAR, 34(1), pp. 11-23. doi: dx.doi. org/10.29313/mimbar.v34i1.2823.1123. 
MIMBAR, Vol. 37, No. $1^{\text {st }}$ (June, 2021), pp. 101-109

Wildan, Sukardi and Syuaib, M. Z. (2016)

'The Feasibility of Development of

Social Capital-Based Ecotourism in West

Lombok', MIMBAR, 32(1), pp. 214-222. 